\title{
Effect of Saccharomyces cerevisiae on alfalfa nutrient degradation characteristics and rumen microbial populations of steers fed diets with different concentrate-to-forage ratios
}

\author{
Gengzhi Ding ${ }^{1}$, Ying Chang ${ }^{2}$, Liping Zhao' ${ }^{1}$ Zhenming Zhou', Liping Ren ${ }^{1}$ and Qingxiang Meng ${ }^{1 *}$
}

\begin{abstract}
Live yeast (Saccharomyces cerevisiae) constitutes an effective additive for animal production; its probiotic effect may be related to the concentrate-to-forage ratio (CTFR). The objective of this study was to assess the effects of $\mathrm{S}$. cerevisiae (SC) on fiber degradation and rumen microbial populations in steers fed diets with different levels of dietary concentrate. Ten Simmental $\times$ Local crossbred steers ( $450 \pm 50 \mathrm{~kg}$ BW) were assigned to a control group or an SC group. Both groups were fed the same basal diet but the SC group received SC supplementation $\left(8 \times 10^{9} \mathrm{cfu} / \mathrm{h} / \mathrm{d}\right.$ through the ruminal fistula) following a two-period crossover design. Each period consisted of four phases, each of which lasted $17 \mathrm{~d}$ : $10 \mathrm{~d}$ for dietary adaptation, $6 \mathrm{~d}$ for degradation study, and $1 \mathrm{~d}$ for rumen sample collection. From the $1^{\text {st }}$ to the $4^{\text {th }}$ phase, steers were fed in a stepwise fashion with increasing CTFRs, i.e., 30:70, 50:50, 70:30, and 90:10. The kinetics of dry matter and fiber degradation of alfalfa pellets were evaluated; the rumen microbial populations were detected using real-time PCR. The results revealed no significant $(P>0.05)$ interactions between dietary CTFR and SC for most parameters. Dietary CTFR had a significant effect $(P<0.01)$ on degradation characteristics of alfalfa pellets and the copies of rumen microorganism; the increasing concentrate level resulted in linear, quadratic or cubic variation trend for these parameters. SC supplementation significantly $(P<0.05)$ affected dry matter (DM) and neutral detergent fiber (NDF) degradation rates $\left(C_{D M}, C_{N D F}\right)$ and NDF effective degradability $\left(E D_{N D F}\right)$. Compared with the control group, there was an increasing trend of rumen fungi and protozoa in SC group $(P<0.1)$; copies of total bacteria in SC group were significantly higher $(P<0.05)$. Additionally, percentage of Ruminobacter amylophilus was significantly lower $(P<0.05)$ but percentage of Selenomonas ruminantium was significantly higher $(P<0.05)$ in the SC group. In a word, dietary CTFR had a significant effect on degradation characteristics of forage and rumen microbial population. $S$. cerevisiae had positive effects on DM and NDF degradation rate or effective degradability of forage; S. cerevisiae increased rumen total bacteria, fungi, protozoa, and lactate-utilizing bacteria but reduced starch-degrading and lactate-producing bacteria.
\end{abstract}

Keywords: Concentrate-to-forage ratios, In situ, Real-time PCR, Rumen microorganism, Steers

\section{Introduction}

Compounds isolated from Saccharomyces cerevisiae have been used as antibiotic substitutes to improve cattle production efficiency, especially after antibiotics were banned by the European Union [1]. Studies have shown that the S. cerevisiae CNCM I-1077 strain (Levucell SC,

\footnotetext{
* Correspondence: qxmeng@cau.edu.cn

'State Key Laboratory of Animal Nutrition, College of Animal Science and Technology, China Agricultural University, Beijing 100193, China Full list of author information is available at the end of the article
}

Lallemand, Toulouse, France) has positive effects on milk production and daily feed intake of dairy cows and goats [2-4]. The primary mechanisms by which live yeasts affect animal performance appears to be related to the effect of yeast on rumen bacterial populations [5], consequently, on nutrient degradation. However, the effect of live yeast on nutrient degradation in the rumen is highly variable. Guedes et al. [6] reported that supplementing cattle with live yeast increased ruminal neutral detergent fiber (NDF) degradation of maize silage, while Mir and Mir [7] reported that live yeast supplementation

\section{Ciomed Central}

(c) 2014 Ding et al.; licensee BioMed Central Ltd. This is an Open Access article distributed under the terms of the Creative Commons Attribution License (http://creativecommons.org/licenses/by/4.0), which permits unrestricted use, distribution, and reproduction in any medium, provided the original work is properly credited. The Creative Commons Public Domain Dedication waiver (http://creativecommons.org/publicdomain/zero/1.0/) applies to the data made available in this article unless otherwise stated. 
had no effects on ruminal dry matter (DM) or NDF degradation. Part of these differences may be attributed to different basal diets, especially levels of dietary concentrates $[8,9]$. According to previous studies [6], probiotic role of live yeast is relating to its effect on stabilizing ruminal $\mathrm{pH}$. However, ruminal $\mathrm{pH}$ is function of the level of concentrate. Hence, the effect of live yeast on nutrient degradation characteristics and rumen bacteria population may be related to concentrate to forage ratios.

Although several studies have reported that S. cerevisiae has positive effects on animal production performance, nutrient degradation, and rumen bacterial population, the majority of these studies focused on dairy cattle and small ruminants such as sheep and goats [2-4]. Few studies have focused on the effects of live yeast on nutrient degradation and rumen microbial population of beef cattle fed different levels of dietary concentrates. Therefore, the objective of this study was to investigate the effects of supplementation with S. cerevisiae (SC) on nutrient degradation and rumen microbial population of beef cattle fed diets with different concentrate-to-forage ratios.

\section{Materials and methods}

Animals, diets, and experimental design

Ten Simmental $\times$ local crossbred steers $(450 \pm 50 \mathrm{~kg}$ body weight) fitted with $10-\mathrm{cm}$ diameter rumen cannulas were used as experimental animals. This study was approved by the Animal Care and Use Committee of the College of Animal Science and Technology of China Agricultural University (ACUC-CAST, \#20120806BCRC004). The steers were individually housed in tie-stall barns, and feed, fresh water were available ad libitum. Steers were randomly assigned to one of two groups: a control group, which received the basal diet with no SC supplementation, or an SC group, which received the basal diet with SC supplementation, following a 2-period crossover design. Each period consisted of four phases; each phase lasted $17 \mathrm{~d}: 16 \mathrm{~d}$ for dietary adaptation and $1 \mathrm{~d}$ for rumen liquor sampling. From the $1^{\text {st }}$ to the $4^{\text {th }}$ phase, steers were fed with increasing dietary concentrate levels in a stepwise fashion. Between periods, steers were fed low level concentrate diet without any treatment during $65 \mathrm{~d}$ as a wash-out period. During the wash-out period, ruminal $\mathrm{pH}$ and protozoa number were monitored until which recovered to normal level. The stepwise diets (Table 1) were formulated to meet the nutrient requirements (NRC, 2000), with concentrate-to-forage ratios (CTFR) of 30:70 (Phase 1), 50:50 (Phase 2), 70:30 (Phase 3), and 90:10 (Phase 4). Prior to each phase, the diets were mixed and pressed into high density bales using a specialized wrapping machine (DK-850C, Jintudi Co, Baoding, China). During the experiment, active dry SC (I-1077, Levucell SC, Lallemand, Toulouse, France) at $8 \times 10^{9} \mathrm{cfu} / \mathrm{h} / \mathrm{d}$ was
Table 1 Ingredients and chemical composition of basal diets

\begin{tabular}{lcccc}
\hline Item & \multicolumn{4}{c}{ Dietary concentrate to forage ratios } \\
\cline { 2 - 5 } & $\mathbf{3 0 : 7 0}$ & $\mathbf{5 0 : 5 0}$ & $\mathbf{7 0 : 3 0}$ & $\mathbf{9 0 : 1 0}$ \\
\hline Ingredient, \% DM & & & & \\
Steam-flaked maize ${ }^{1}$ & 13.00 & 34.00 & 54.00 & 74.00 \\
Soybean curb residue $^{2}$ & 15.20 & 13.90 & 13.70 & 13.30 \\
Maize stalks & 57.00 & 38.00 & 19.00 & 1.00 \\
Chinese ryegrass & 4.00 & 5.00 & 6.00 & 6.00 \\
Alfalfa pellets & 9.00 & 7.00 & 5.00 & 3.00 \\
Salt & 0.50 & 0.50 & 0.50 & 0.50 \\
Limestone & 0.40 & 0.70 & 1.10 & 1.50 \\
Dicalcium phosphate & 0.20 & 0.20 & 0.00 & 0.00 \\
Magnesium oxide & 0.20 & 0.20 & 0.20 & 0.20 \\
Sodium bicarbonate & 0.50 & 0.50 & 0.50 & 0.50 \\
Composition, \% DM & & & & \\
ME, MJ/kg & 9.10 & 10.30 & 11.70 & 12.80 \\
CP & 12.70 & 12.70 & 12.70 & 12.80 \\
aNDF & 54.20 & 42.70 & 31.60 & 20.80 \\
Starch & 12.20 & 26.80 & 40.90 & 54.20 \\
Ca & 0.64 & 0.64 & 0.63 & 0.67 \\
P & 0.32 & 0.34 & 0.33 & 0.35 \\
\hline
\end{tabular}

${ }^{1}$ Flaking density is $360 \mathrm{~g} / \mathrm{L}$.

${ }^{2} \mathrm{~A}$ by-product comes from soybean processed into bean curd which is a kind of food in China.

added directly into the rumen through the cannulas just prior to the morning feeding.

\section{In situ rumen incubation}

Alfalfa pellets were passed through a $2-\mathrm{mm}$ screen in a Wiley laboratory mill; $5 \mathrm{~g}$ DM was transferred to separate number-coded nylon bags $(8 \mathrm{~cm} \times 12 \mathrm{~cm})$ of $38 \mu \mathrm{m}$ pore size. For incubation purposes, each steer had a total of three bags per sample. Rumen incubations were performed according to the method of Ørskov et al. [10] but following the gradual addition/all out schedule [11]. Samples were incubated in the rumen for $168,96,48$, $24,12,6$, and $0 \mathrm{~h}$, respectively; for NDF, the samples were incubated for $240 \mathrm{~h}$. All bags were inserted at the same time $(0800 \mathrm{~h})$ just prior to the morning feeding and apart from the $12 \mathrm{~h}$ bags and $6 \mathrm{~h}$ bags, which were inserted at $0700 \mathrm{~h}$ and $1300 \mathrm{~h}$. Following incubation, the bags were removed from the rumen and rinsed with cold tap water to remove excess ruminal contents and to remove microbial activity. The bags were washed with cold water without detergent in a washing machine and dried at $60^{\circ} \mathrm{C}$ for $48 \mathrm{~h}$. The $0 \mathrm{~h}$ incubation samples were only washed. The bags were weighed and residues were pooled according to group and incubation times and passed through a 1-mm screen. DM and NDF were analyzed. Data for DM and NDF disappearance at 
different incubation times were fitted to the following models [10],

$$
\begin{aligned}
& \mathrm{p}=a+b \times\left(1-\mathrm{e}^{-c t}\right) \\
& \mathrm{ED}=a+b \times c /(c+k)
\end{aligned}
$$

where $p$ is the fraction disappearance at time $t ; a$ is the soluble or rapidly degradable fraction; $b$ is the insoluble but potentially degradable fraction; $c$ is the rate constant of degradation of potentially degradable insoluble fraction $(/ \mathrm{h}) ; t$ is the time of rumen incubation $(\mathrm{h}) ; k$ is the rumen passage rate $(/ \mathrm{h})$, and $E D$ is the effective degradability. In this experiment, $k=0.03 / \mathrm{h}$ was used [12]. DM in feedstuff and residues was measured by drying the samples at $60^{\circ} \mathrm{C}$ for $48 \mathrm{~h}$ in a forced-air oven. NDF [13] was measured using an ANKOM $^{200}$ Fiber Analyzer (ANKOM Technology Corp., Fairport, NY, USA). NDF was assayed with heat stable amylase (aNDF) and without sodium sulfite; NDF results included residual ash [14].

\section{Ruminal fluid collection}

On the last day of each phase, rumen samples were collected by hand from four locations in the rumen and reticulum through rumen cannulas at $3 \mathrm{~h}$ after the morning feeding. Aliquots were filtered through two layers of cheese cloth; $40 \mathrm{~mL}$ of the filtered rumen fluid was transferred to $50-\mathrm{mL}$ centrifuge tubes, which were flash frozen in liquid nitrogen, transferred to the laboratory, and stored at $-80^{\circ} \mathrm{C}$ prior to DNA extraction; these steps lasted $10 \mathrm{~min}$.

\section{DNA extraction and real-time PCR}

Total genomic DNA from $200 \mu \mathrm{L}$ of frozen rumen samples was extracted using TIANGEN ${ }^{\circ}$ TIANamp Stool DNA Kit (Tiangen Biotech Co., Ltd., Beijing, China). DNA concentration and purity $\left(\mathrm{OD}_{260 / 280}\right.$ and $\mathrm{OD}_{260 / 230}$, respectively) were determined using the NanoDrop ND-1000 spectrophotometer (NanoDrop Technologies).

Quantitative real-time PCR was performed with the 7300 Real-Time PCR System (Applied Biosystems) using SYBR green chemistry (SuperReal PreMix Plus, Tiangen Biotech Co., Ltd.). The primers of target microorganism are shown in Table 2. DNA extract $(1 \mu \mathrm{L})$ was added to the amplification reaction $(20 \mu \mathrm{L})$, containing $0.3 \mu \mathrm{L}$ of each primer, $7.9 \mu \mathrm{L}$ of $2 \times$ SuperReal PreMix Plus (with SYBR Green), $8 \mu \mathrm{L}$ of $\mathrm{ddH}_{2} \mathrm{O}$, and $2.5 \mu \mathrm{L}$ of $50 \times \mathrm{ROX}$ Reference Dye. The thermal cycling conditions consisted of an initial Taq activation step at $95^{\circ} \mathrm{C}$ for $15 \mathrm{~min}$, followed by 40 cycles of $95^{\circ} \mathrm{C}$ for $15 \mathrm{~s}$ and of $60^{\circ} \mathrm{C}$ for $30 \mathrm{~s}$, followed by an amplicon dissociation stage $\left(95^{\circ} \mathrm{C}\right.$ for $15 \mathrm{~s}$ and $60^{\circ} \mathrm{C}$ for $1 \mathrm{~min}$, increasing $0.5^{\circ} \mathrm{C} /$ cycle until $95^{\circ} \mathrm{C}$ was reached), which confirmed specificity via dissociation curve analysis of PCR end products. Fluorescence detection was performed at the end of each denaturation and
Table 2 Primers used in real-time PCR for the detection

\begin{tabular}{|c|c|c|}
\hline $\begin{array}{l}\text { Target } \\
\text { bacterium }\end{array}$ & Primer sequence $\left(5^{\prime}-3^{\prime}\right)$ & References \\
\hline \multirow[t]{2}{*}{ Total bacteria } & F, CGGCAACGAGCGCAACCC & [15] \\
\hline & R, CCATTGTAGCACGTGTGTAGCC & \\
\hline \multirow[t]{2}{*}{ Rumen fungi } & F, GAGGAAGTAAAAGTCGTAACAAGGTTTC & [16] \\
\hline & R, CAAATTCACAAAGGGTAGGATGATT & \\
\hline \multirow[t]{2}{*}{ Protozoa } & F, GCTTTCGWTGGTAGTGTATT & [16] \\
\hline & R, CTTGCCCTCYAATCGTWCT & \\
\hline \multirow{2}{*}{$\begin{array}{l}\text { Ruminobacter } \\
\text { ablus }\end{array}$} & F, TGTTAACAGAGGGAAGCAAAGCA & [17] \\
\hline & R, TGCAGCCTACAATCCGAACTAA & \\
\hline \multirow{2}{*}{$\begin{array}{l}\text { Ruminococcus } \\
\text { flavefaciens }\end{array}$} & F, TGGCGGACGGGTGAGTAA & [17] \\
\hline & R, TTACCATCCGTTTCCAGAAGCT & \\
\hline \multirow{2}{*}{$\begin{array}{l}\text { Butyrivibrio } \\
\text { fibrisolvens }\end{array}$} & F, ACCGCATAAGCGCACGGA & [17] \\
\hline & R, CGGGTCCATCTTGTACCGATAAAT & \\
\hline \multirow{2}{*}{$\begin{array}{l}\text { Fibrobacter } \\
\text { succinogenes }\end{array}$} & F, GCGGGTAGCAAACAGGATTAGA & [17], [18] \\
\hline & R, CCCCCGGACACCCAGTAT & \\
\hline \multirow{2}{*}{$\begin{array}{l}\text { Selenomonas } \\
\text { ruminantium }\end{array}$} & F, CAATAAGCATTCCGCCTGGG & [17], [18] \\
\hline & R, TTCACTCAATGTCAAGCCCTGG & \\
\hline \multirow{2}{*}{$\begin{array}{l}\text { Streptococcus } \\
\text { bovis }\end{array}$} & F, CTAATACCGCATAACAGCAT & [19] \\
\hline & R, AGAAACTTCCTATCTCTAGG & \\
\hline \multirow{2}{*}{$\begin{array}{l}\text { Ruminobacter } \\
\text { amylophilus }\end{array}$} & F, CAACCAGTCGCATTCAGA & [19] \\
\hline & R, CACTACTCATGGCAACAT & \\
\hline \multirow[t]{2}{*}{ Lactobacillus } & F, AGCAGTAGGGAATCTTCCA & {$[20]$} \\
\hline & R, CGCCACTGGTGTTCYTCCATATA & \\
\hline
\end{tabular}
of rumen microorganism

extension step. For robustness, 3 replicates of each DNA sample were analyzed in the same plate.

For the absolute quantification of total bacteria $16 \mathrm{~S}$ rDNA, rumen fungi and protozoa $18 \mathrm{~S}$ rDNA gene copies, total bacteria, fungi and protozoa rDNA extracts from mixed rumen samples were loaded on a $1 \%$ agarose gel and visualized by ethidium bromide staining respectively. The resulting products were purified using the TIANGEN ${ }^{\circ}$ TIANgel Midi Purification Kit (Tiangen Biotech Co., Ltd.). The purified PCR product was used as a standard whose concentration was measured in the ND-1000 spectrophotometer and converted to concentration using the following equation, DNA (number of molecules) $=\left(\mathrm{NL} \times \mathrm{A} \times 10^{-9}\right) /$ $(660 \times n)$, where NL is the Avogadro constant $\left(6.02 \times 10^{23}\right.$ molecules per mol); A is the molecular weight of the molecule in the standard; and $\mathrm{n}$ is the length of the amplicon in base pairs [21]. Standard curves were constructed with purified total bacteria, rumen fungi, and protozoa rDNA when the copies of total bacteria, rumen fungi, and protozoa were measured.

For quantification of individual species, Relative Quantification $\triangle C T$ method [22] was used and the total bacteria used as reference. Amplification efficiencies were 
calculated using serial dilutions and only efficiencies between $90 \%-110 \%$ were taken into consideration.

\section{Statistical analyses}

SAS (1990) software was used for statistical analyses. Nutrient degradation data and rumen microbial population data were analyzed using the MIXED procedure with the following model,

$$
\begin{aligned}
Y_{i j k l}= & \mu+\text { Period }_{i}+\text { Treatment }_{j}+\text { Diet }_{k} \\
& +\left(\text { Treatment }_{j} \times \text { Diet }_{k}\right)+\text { Steer }_{l}+\varepsilon_{i j k l}
\end{aligned}
$$

where $\mu$ represented the overall mean, Period represented the period (1 or 2), Treatment accounted for the fixed effect of yeast supplementation, Diet represented the fixed effect of different dietary CTFR, Steer accounted for the random effect of each individual animal, $\varepsilon$ account for the unexplained random error. Linear, quadratic and cubic responses for dietary CTFR were assessed using orthogonal polynomial contrast statements.

\section{Results}

The results revealed that there were no significant difference between the 2 periods and there were no interactions between dietary CTFR and SC $(P>0.1$; Tables 3,4 and 5) for most parameters except $a_{\mathrm{DM}}, c_{\mathrm{NDF}}$, and copies of $R$. ablus. Therefore, the main effects of diet and SC are discussed independently.

\section{Effect of diet on alfalfa pellet degradation}

The degradation characteristics of alfalfa pellet DM are shown in Table 3 . There were statistically significant differences $(P<0.01)$ in $a_{\mathrm{DM}}, b_{\mathrm{DM}}, c_{\mathrm{DM}}$, and $\mathrm{ED}_{\mathrm{DM}}$ among the different diets. Increasing concentrate level resulted in a cubic variation trend in $a_{\mathrm{DM}}$ and $b_{\mathrm{DM}}(P<0.05)$, and a linear and quadratic decrease in $c_{\mathrm{DM}}$ and $\mathrm{ED}_{\mathrm{DM}}$ respectively $(P<0.01)$.

The degradation characteristics of alfalfa pellet NDF are shown in Table 4 . Dietary CTFR significantly $(P<$ 0.01 ) affected NDF degradation characteristics and the variation trends were similar to those obtained for DM.

\section{Effect of SC on alfalfa pellet degradation}

There were no significant differences $(P>0.05)$ in $a_{\mathrm{DM}}$, $b_{\mathrm{DM}}$, or $\mathrm{ED}_{\mathrm{DM}}$ of alfalfa pellet between the $\mathrm{SC}$ and control groups (Table 3). However, SC supplementation increased $(P<0.01) c_{\mathrm{DM}}$ of alfalfa pellet compared to the control group.

There were no differences in $a_{\mathrm{NDF}} b_{\mathrm{NDF}}(P>0.05)$ between the SC and control groups (Table 4); however, $c_{\mathrm{NDF}}$ and $\mathrm{ED}_{\mathrm{NDF}}$ of $\mathrm{SC}$ were significantly different from that of the control group $(P<0.05)$.

The relative DM effective degradability had an increasing trend with increasing dietary CTFR and it reached $5.93 \%$ (calculated from $45.03 \%-42.51 \%$ ) $/ 42.51 \% \times 100 \%$ ) when dietary CTFR was 90:10.

In addition, the relative NDF effective degradability presented an increasing trend with increasing dietary CTFR and it reached $9.49 \%$ (calculated from 23.38\%-21. 35\%)/ $21.35 \% \times 100 \%$ ) when dietary CTFR was 90:10.

\section{Effect of diet on rumen microbial population}

There were significant differences $(P<0.01)$ in rumen microbial population among the four phases (Table 5). With increasing dietary concentrate levels, percentage of Butyrivibrio fibrisolvens and Lactobacillus species linearly decreased and increased respectively $(P<0.01)$; percentage of Fibrobacter succinogenes and Ruminobacter amylophilus quadratically decreased respectively $(P<0.01)$; total bacteria, fungi, protozoa and other target bacteria presented cubic variation trend $(P<0.05)$.

\section{Effect of SC on rumen microbial population}

The total bacteria copies in the SC group were significantly higher $(P<0.05)$ than in the control group (Table 5). The copies of rumen fungi and protozoa with SC supplementation increased $(P<0.1)$ compared to the control group. When $\mathrm{SC}$ was supplemented, the percentage of $R$. amylophilus and $S$. ruminantium significantly $(P<0.05)$ decreased and increased, respectively. However, there were no significant differences $(P>0.05)$ in other bacterial species.

Table 3 Effect of SC supplementation on dry matter (DM) degradation characteristics of alfalfa pellets in steers fed

\begin{tabular}{|c|c|c|c|c|c|c|c|c|c|c|c|c|c|c|}
\hline \multirow[t]{2}{*}{ Item } & \multicolumn{4}{|c|}{ CTFR } & \multirow[t]{2}{*}{ SEM } & \multicolumn{2}{|c|}{ SC } & \multirow[t]{2}{*}{ SEM } & \multicolumn{3}{|c|}{$P$-value } & \multicolumn{3}{|c|}{ Probability $^{3}$} \\
\hline & $30: 70$ & $50: 50$ & $70: 30$ & $90: 10$ & & $\mathrm{~N}^{1}$ & $Y^{2}$ & & CTFR & SC & $\mathrm{CTFR} \times \mathrm{SC}$ & Linear & Quadratic & Cubic \\
\hline$a, \%$ & 26.07 & 29.46 & 27.08 & 26.58 & 0.64 & 27.46 & 27.14 & 0.45 & $<0.01$ & 0.61 & 0.09 & 0.80 & 0.01 & 0.03 \\
\hline$b, \%$ & 38.48 & 35.95 & 38.99 & 39.86 & 0.75 & 38.18 & 38.46 & 0.53 & $<0.01$ & 0.71 & 0.43 & 0.05 & 0.04 & 0.04 \\
\hline$c, \% / h$ & 3.50 & 3.30 & 3.00 & 2.47 & 0.14 & 2.86 & 3.29 & 0.10 & $<0.01$ & 0.04 & 0.14 & $<0.01$ & 0.25 & 0.96 \\
\hline$E D, \%$ & 46.54 & 48.48 & 46.62 & 43.76 & 0.32 & 45.65 & 47.06 & 0.22 & $<0.01$ & $<0.01$ & 0.14 & $<0.01$ & $<0.01$ & 0.12 \\
\hline
\end{tabular}
diets with different concentrate-to-forage ratios

${ }^{1} \mathrm{~N}$ : without yeast supplementation;

${ }^{2} Y$ : with yeast supplementation;

${ }^{3}$ Linear indicates linear effect of dietary CTFR; quadratic indicates a quadratic effect of dietary CTFR; cubic indicates a cubic effect of dietary CTFR. 
Table 4 Effect of SC supplementation on neutral detergent fiber (NDF) degradation characteristics of alfalfa pellets in steers fed diets with different concentrate-to-forage ratios

\begin{tabular}{|c|c|c|c|c|c|c|c|c|c|c|c|c|c|c|}
\hline \multirow[t]{2}{*}{ Item } & \multicolumn{4}{|c|}{ CTFR } & \multirow[t]{2}{*}{ SEM } & \multicolumn{2}{|c|}{ SC } & \multirow[t]{2}{*}{ SEM } & \multicolumn{3}{|c|}{$P$-value } & \multicolumn{3}{|c|}{ Probability $^{3}$} \\
\hline & $30: 70$ & $50: 50$ & $70: 30$ & $90: 10$ & & $\mathrm{~N}^{1}$ & $Y^{2}$ & & CTFR & SC & $\mathrm{CTFR} \times \mathrm{SC}$ & Linear & Quadratic & Cubic \\
\hline$a, \%$ & 2.32 & 6.36 & 2.70 & 2.99 & 0.74 & 3.22 & 3.96 & 0.52 & $<0.01$ & 0.32 & 0.13 & 0.67 & 0.03 & $<0.01$ \\
\hline$b, \%$ & 46.77 & 44.76 & 49.29 & 49.69 & 0.92 & 48.11 & 47.15 & 0.65 & $<0.01$ & 0.30 & 0.35 & $<0.01$ & 0.24 & 0.02 \\
\hline$c, \% / h$ & 3.40 & 2.77 & 2.55 & 1.83 & 0.11 & 2.52 & 2.76 & 0.08 & $<0.01$ & 0.03 & 0.04 & $<0.01$ & 0.95 & 0.24 \\
\hline$E D, \%$ & 26.89 & 27.35 & 25.28 & 22.36 & 0.44 & 24.70 & 26.25 & 0.31 & $<0.01$ & $<0.01$ & 0.56 & $<0.01$ & $<0.01$ & 0.47 \\
\hline
\end{tabular}

${ }^{1} \mathrm{~N}$ : without yeast supplementation;

${ }^{2} \mathrm{Y}$ : with yeast supplementation:

${ }^{3}$ Linear indicates linear effect of dietary CTFR; quadratic indicates a quadratic effect of dietary CTFR; cubic indicates a cubic effect of dietary CTFR.

\section{Discussion}

There was an interaction of dietary CTFR and SC supplementation on $a_{\mathrm{DM}}, c_{\mathrm{NDF}}$ and copies of $R$. ablus, which can be illustrated by polynomial contrast results and visually shown in Figures 1, 2, 3 and 4. Without yeast, $a_{\mathrm{DM}}$ showed quadratic variation trend (Quadratic, $P<0.01$ ), with yeast $a_{\mathrm{DM}}$ presented cubic variation trend (Cubic, $P<0.05$ ). Similarly, SC supplementation changed the variation trend of $c_{\mathrm{NDF}}$, and copies of $R$. ablus. The interaction suggested that SC possess biological effect on fiber degradation, which was related to dietary concentrate to forage ratio.

Roughage is degraded by fiber-degrading bacteria; however, the major fiber-degrading bacteria such as $F$. succinogenes, $R$. ablus, and $R$. flavfaciens are sensitive to low $\mathrm{pH}$ values. With increasing dietary concentrate levels, more sugars, starch, and other non-structural carbohydrates are consumed, which contribute to a higher concentration of volatile fatty acids (VFAs). Higher VFA concentrations reduce ruminal $\mathrm{pH}$ values and, consequently, the number and activities of fiberdegrading bacteria decreased. Therefore, the effect of dietary CTFR on $a_{\mathrm{DM}} / a_{\mathrm{NDF}}, b_{\mathrm{DM}} / b_{\mathrm{NDF}}, c_{\mathrm{DM}} / c_{\mathrm{NDF}}$, and $\mathrm{ED}_{\mathrm{DM}} / \mathrm{ED}_{\mathrm{NDF}}$ can easily be understood. On the other hand, with increasing dietary concentrate levels, the percentage of lactate-producing bacteria such as $S$. bovis and Lactobacillus increased; however, lactate-utilizing

Table 5 Effect of SC supplementation on rumen microbial populations and percentage of target species relative to total bacteria of steers fed diets with different concentrate-to-forage ratios

\begin{tabular}{|c|c|c|c|c|c|c|c|c|c|c|c|c|c|c|}
\hline \multirow[t]{2}{*}{ Item } & \multicolumn{4}{|c|}{ CTFR } & \multirow[t]{2}{*}{ SEM } & \multicolumn{2}{|c|}{ SC } & \multirow[t]{2}{*}{ SEM } & \multicolumn{3}{|c|}{$P$-value } & \multicolumn{3}{|c|}{ Probability $^{3}$} \\
\hline & $30: 70$ & $50: 50$ & $70: 30$ & $90: 10$ & & $\overline{N^{1}}$ & $\mathrm{Y}^{2}$ & & CTFR & SC & $\overline{C T F R} \times \mathrm{SC}$ & Linear & Quadratic & Cubic \\
\hline $\begin{array}{l}\text { Total bacteria, } \\
\times 10^{10} \text { copies } / \mathrm{mL}\end{array}$ & 6.95 & 9.62 & 13.08 & 6.21 & 1.09 & 7.86 & 10.07 & 0.77 & $<0.01$ & 0.05 & 0.61 & 0.82 & $<0.01$ & 0.04 \\
\hline $\begin{array}{l}\text { Rumen fungi, } \\
\times 10^{5} \text { copies } / \mathrm{mL}\end{array}$ & 6.57 & 5.10 & 11.80 & 3.57 & 0.91 & 5.99 & 7.51 & 0.64 & $<0.01$ & 0.10 & 0.22 & 0.63 & $<0.01$ & $<0.01$ \\
\hline $\begin{array}{l}\text { Protozoa, } \\
\times 10^{5} \text { copies } / \mathrm{mL}\end{array}$ & 4.03 & 3.64 & 17.44 & 7.44 & 1.47 & 6.74 & 9.54 & 1.04 & $<0.01$ & 0.06 & 0.30 & $<0.01$ & $<0.01$ & $<0.01$ \\
\hline Percentage relativ & to total & acteria & & & & & & & & & & & & \\
\hline R. flavefaciens & 0.45 & 0.20 & 0.28 & 0.16 & 0.03 & 0.25 & 0.29 & 0.02 & $<0.01$ & 0.25 & 0.87 & $<0.01$ & 0.07 & $<0.01$ \\
\hline R. ablus & 0.02 & 0.01 & 0.01 & 0.00 & 0.00 & 0.01 & 0.01 & 0.00 & $<0.01$ & 0.63 & 0.08 & $<0.01$ & 0.40 & 0.02 \\
\hline FibSuc $^{4}$ & 1.03 & 0.39 & 0.23 & 0.11 & 0.09 & 0.46 & 0.43 & 0.06 & $<0.01$ & 0.72 & 0.85 & $<0.01$ & 0.03 & 0.41 \\
\hline ButFib $^{5}$ & 0.01 & 0.01 & 0.00 & 0.00 & 0.00 & 0.01 & 0.01 & 0.00 & $<0.01$ & 0.37 & 0.61 & $<0.01$ & 0.68 & 0.75 \\
\hline StrBov 6 & 0.03 & 0.05 & 0.01 & 0.01 & 0.00 & 0.03 & 0.02 & 0.00 & $<0.01$ & 0.64 & 0.83 & $<0.01$ & $<0.01$ & $<0.01$ \\
\hline RumAmy ${ }^{7}$ & 0.13 & 0.14 & 0.10 & 0.07 & 0.01 & 0.12 & 0.10 & 0.01 & $<0.01$ & 0.01 & 0.53 & $<0.01$ & 0.03 & 0.19 \\
\hline SelRum ${ }^{8}$ & 3.10 & 3.24 & 1.80 & 1.07 & 0.21 & 2.04 & 2.55 & 0.15 & $<0.01$ & 0.02 & 0.46 & $<0.01$ & 0.09 & 0.05 \\
\hline Lactobacillus $^{9}$ & 0.02 & 0.02 & 0.04 & 0.05 & 0.01 & 0.04 & 0.03 & 0.01 & $<0.01$ & 0.16 & 0.73 & $<0.01$ & 0.51 & 0.14 \\
\hline
\end{tabular}

${ }^{1} \mathrm{~N}$ : without yeast supplementation;

${ }^{2} \mathrm{Y}$ : with yeast supplementation;

${ }^{3}$ Linear indicates linear effect of dietary CTFR; quadratic indicates a quadratic effect of dietary CTFR; cubic indicates a cubic effect of dietary CTFR;

${ }^{4}$ FibSuc: Fibrobacter succinogenes;

${ }^{5}$ ButFib: Butyrivibrio fibrisolvens;

${ }^{6}$ StrBov: Streptococcus bovis;

${ }^{7}$ RumAmy: Ruminobacter amylophilus;

${ }^{8}$ SelRum: Selnomonas ruminantium;

9 Lactobacillus: Lactobacillus species. 


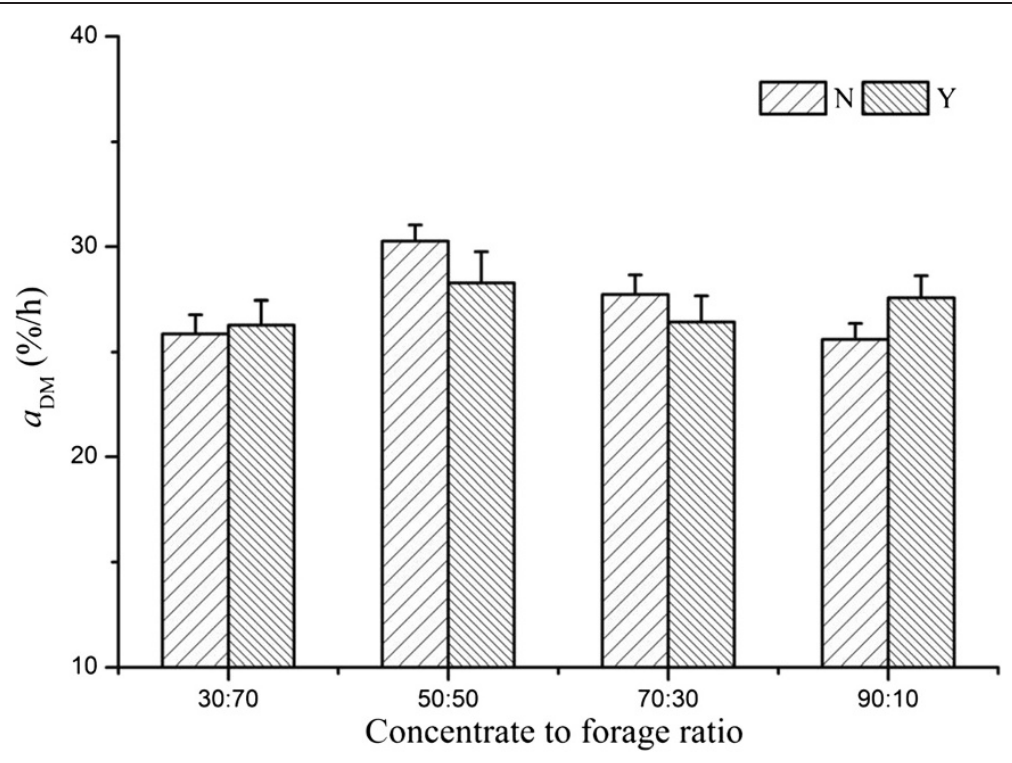

Figure 1 Effect of $\mathrm{SC}$ on $a_{\mathrm{DM}}$ of alfalfa pellet of steers fed different concentrate to forage ratios $\mathrm{N}$ : without yeast supplementation; $\mathrm{Y}$ : with yeast supplementation.

species such as S. ruminantium decreased (Table 5), therefore, lactate may accumulate in the rumen. Consequently, rumen $\mathrm{pH}$ declined and total bacteria, fungi, and protozoa levels rapidly declined (Table 5 ).

When SC was supplemented, total bacteria, fungi, protozoa, fiber-degrading, and lactate-utilizing bacteria increased while starch-degrading and lactate-producing bacteria decreased. Meanwhile, degradation rate or effective degradability of alfalfa DM and NDF improved (Tables 3, 4 and 5). According to Chaucheyras-Durand et al. [5], the probiotic role of SC is attributed to several factors. Firstly, SC possesses the capacity to scavenge unnecessary oxygen in the rumen, reducing the redox potential [23,24]. Therefore, SC contributes to an ecological condition that favors the growth and activities of anaerobic microorganisms and of fiber-degrading bacteria, which improve the DM and NDF degradation rate or effective degradability [6]. Secondly, SC provides thiamin, which is required by fungi for zoosporogenesis [25]. Rumen fungi play important roles in fiber degradation. Thirdly, SC outcompetes starch-degrading bacteria

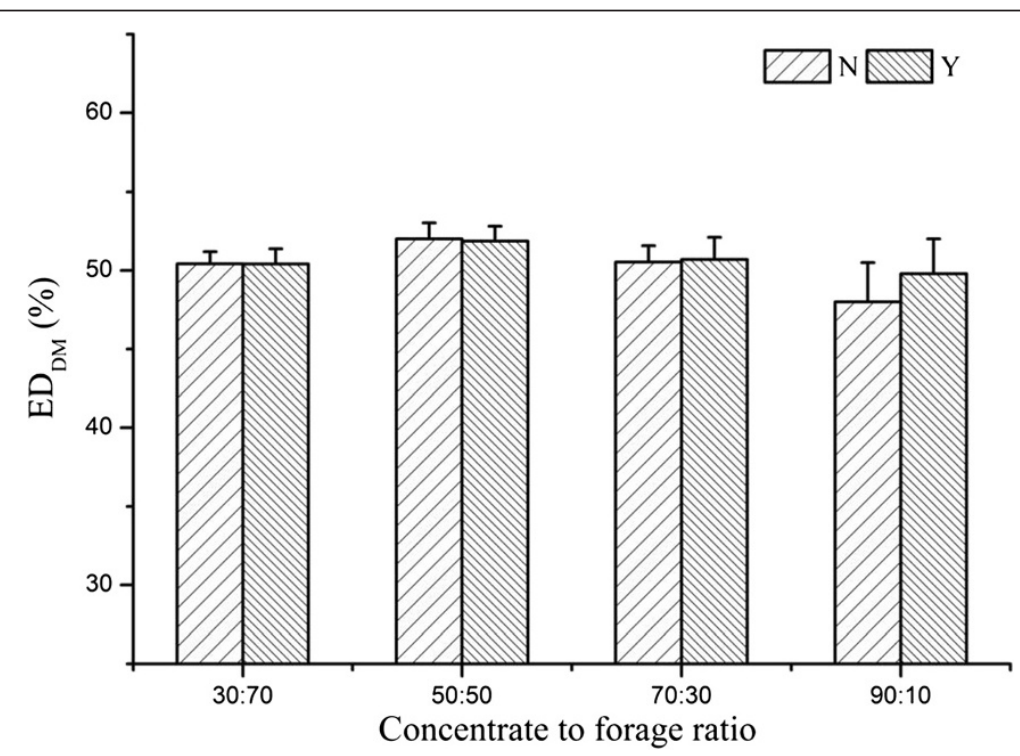

Figure 2 Effect of $\mathrm{SC}$ on $\mathrm{ED}_{\mathrm{DM}}$ of alfalfa pellet of steers fed different concentrate to forage ratios $\mathrm{N}$ : without yeast supplementation; Y: with yeast supplementation. 


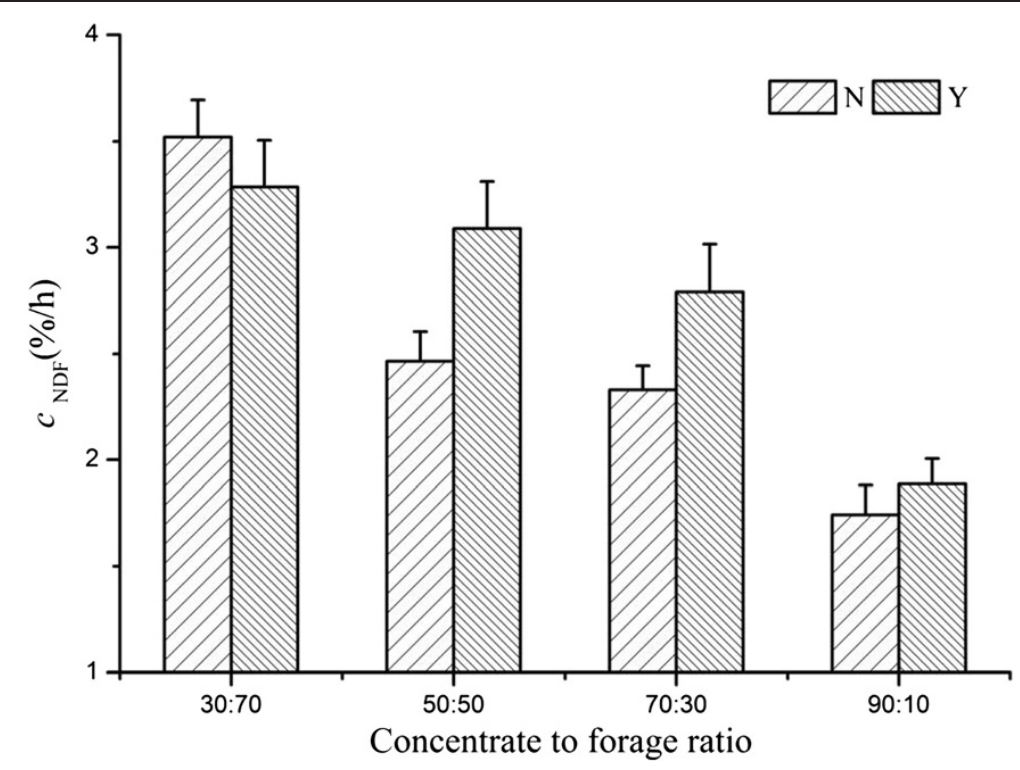

Figure 3 Effect of $\mathrm{SC}$ on $c_{\mathrm{NDF}}$ of alfalfa pellet of steers fed different concentrate to forage ratios $\mathrm{N}$ : without yeast supplementation; Y: with yeast supplementation.

such as S. bovis and Ruminobacter amylophilus for carbohydrate utilization [5]. As a result, rumen VFA concentration was lower in SC than in the control group [26]. Moreover, SC provides growth factors such as amino acids, peptides, and organic acids, which are essential for lactate-utilizing bacteria $[27,28]$; consequently, the number of lactateutilizing bacteria such as S. ruminantium improved significantly (Table 5) and the concentration of lactate was reduced [29]. In addition, SC can stimulate rumen protozoa especially ciliate Entodiniomorphid protozoa, which rapidly engulf starch granules and stabilize ruminal $\mathrm{pH}$ [3]; the same effect of SC on protozoa was obtained in this study (Table 5). The conclusions of Chaucheyras-Durand et al. (2008) were obtained by in vitro experiments, and some experts doubted whether the SC can play the same important role in vivo as in vitro. This experiment proved that in vivo SC really has a positive effect on nutrient degradation and rumen microorganism balance [5].

One the other hand, the effect of SC on rumen nutrient degradation characteristics was inconsistent. For

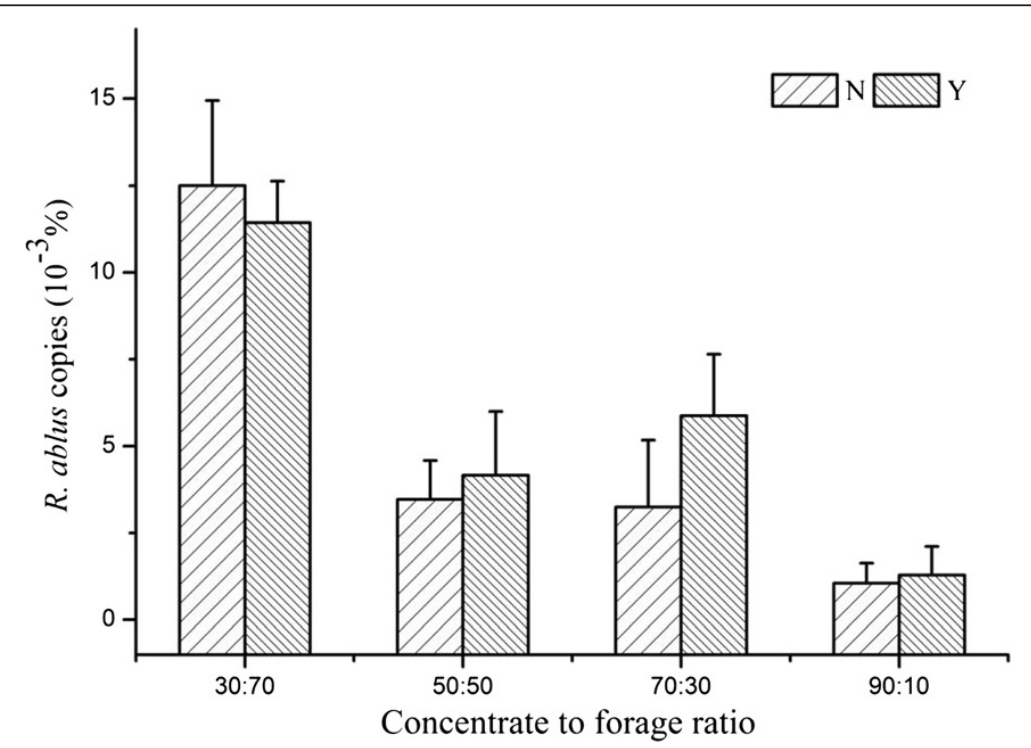

Figure 4 Effect of SC on percentage of $R$. ablus of steers fed different concentrate to forage ratios $\mathrm{N}$ : without yeast supplementation; $\mathrm{Y}$ : with yeast supplementation. 
example, results from this and previous studies revealed that $\mathrm{SC}$ supplementation improved the degradation rate or effective degradability of forage feedstuff [6,30]. However, other studies revealed that SC supplementation had no effects on DM or NDF degradation [31]. The inconsistent results of SC on forage nutrient degradation characteristics may be related to the dietary concentrate-to-forage ratios.

\section{Conclusions}

Dietary CTFR had a significant effect on degradation characteristics of forage and rumen microbial population. S. cerevisiae had positive effects on DM and NDF degradation rate or effective degradability of forage; $S$. cerevisiae increased rumen total bacteria, fungi, protozoa, and lactate-utilizing bacteria but reduced starch-degrading and lactate-producing bacteria.

\section{Competing interests}

The authors declare that they have no competing interests.

\section{Authors' contributions}

QXM and YC conceived the study and designed the experiment. GZD carried out the statistical analysis and drafted the manuscript. GZD, LPZ, ZMZ and LPR performed the animal experiments and rumen microbial population studies. All authors read and approved the final manuscript.

\section{Acknowledgements}

This study was financially supported by the Earmarked Fund for Modern Agro-Industry Technology Research System (Beef Cattle and Yaks, CARS-38), and the Chinese Universities Scientific Fund (No. 2013QT034)". The authors acknowledge the Lallemand (China) for supplying the yeast products.

\section{Author details}

${ }^{1}$ State Key Laboratory of Animal Nutrition, College of Animal Science and Technology, China Agricultural University, Beijing 100193, China. ${ }^{2}$ Lallemand biology Technology (Beijing) Co. Ltd., Beijing, China.

Received: 3 March 2014 Accepted: 25 April 2014

Published: 1 May 2014

\section{References}

1. Anadón A: The EU ban of antibiotics as feed additives: alternatives and consumer safety. J Vet Pharmacol Therap 2006, 29(Suppl 1):41-46.

2. de Ondarza MB, Sniffen CJ, Graham H, Wilcock P: Case study: Effect of Supplemental Live Yeast on Yield of Milk and Milk Components in High-Producing Multiparous Holstein Cows. The Professional Animal Scientist 2010, 26:443-449.

3. Brossard L, Chaucheyras-Durand F, Michalet-Doreauand B, Martin C: Dose effect of live yeasts on rumen microbial communities and fermentations during butyric latent acidosis in sheep: new type of interaction. Anim Sci 2006, 82(6):829-836.

4. Moallem $U$, Lehrer $H$, Livshitz $L$, Zachut M, Yakoby $S$ : The effects of live yeast supplementation to dairy cows during the hot season on production, feed efficiency, and digestibility. J Dairy Sci 2009, 92(1):343-351.

5. Chaucheyras-Durand F, Walker ND, Bach A: Effects of active dry yeasts on the rumen microbial ecosystem: Past, present and future. Anim Feed Sci Tech 2008, 145(1-4):5-26.

6. Guedes CM, Gongalves D, Rodrigues MAM, Dias-da-Silva A: Effects of a Saccharomyces cerevisiae yeast on ruminal fermentation and fibre degradation of maize silages in cows. Anim Feed Sci Tech 2008, 145(1-4):27-40.

7. Mir Z, Mir PS: Effect of the Addition of Live Yeast (Saccharomyces cerevisiae) on Growth and Carcass Quality of Steers Fed High-Forage or High Grain Diets and on Feed Digestibility and In Situ Degradability. J Anim Sci 1994, 72(3):537-545.
8. Stella AV, Paratte R, Valnegri L, Cigalino G, Soncini G, Chevaux E, Dell'Orto Savoini G: Effect of administration of live Saccharomyces cerevisiae on milk production, milk composition, blood metabolites, and faecal flora in early lactating dairy goats. Small Rumin Res 2007, 67(1):7-13.

9. Desnoyers M, Giger-Reverdin S, Bertin G, Duvaux-Ponter C, Sauvant D: Metaanalysis of the influence of Saccharomyces cerevisiae supplementation on ruminal parameters and milk production of ruminants. J Dairy Sci 2009, 92(4):1620-1632

10. Ørskov ER, DeB Hovell FD, Mould F: The use of the nylon bag technique for the evaluation of feedstuffs. Trop Anim Prod 1980, 5(3):195-213.

11. Yu P, Niu Z: Using a complex non-TDN based model (the DVE/OEB system) to predict microbial protein synthesis, endogenous protein, degradation balance, and total truly absorbed protein supply of different varieties of cereal oats for ruminants. Anim Sci J 2009, 80(3):273-279.

12. Alexandrov AN: Effect of ruminal exposure and subsequent microbial contamination of dry matter and protein degradability of various feedstuffs. Anim Feed Sci Tech 1998, 71(1-2):99-107.

13. Van Soest PJ, Robertson JB, Lewis BA: Methods for dietary fiber neutral detergent fiber, and non-starch polysaccharides in relation to animal nutrition. J Dairy Sci 1991, 74(10):3583-3597.

14. Hristov AN, Varga G, Cassidy T, Long M, Heyler K, Karnati SKR, Corl B, Hovde CJ, Yoon I: Effect of Saccharomyces cerevisiae fermentation product on ruminal fermentation and nutrient utilization in dairy cows. J Dairy Sci 2010, 93(2):682-692.

15. Denman SE, McSweeney CS: Development of a real-time PCR assay for monitoring anaerobic fungal and cellulolytic bacterial populations within the rumen. FEMS Microbiol Ecol 2006, 58(3):572-582.

16. Carberry CA, Kenny DA, Han S, McCabe MS, Waters SM: Effect of phenotypic residual feed intake and dietary forage content on the rumen microbial community of beef cattle. Appl Environ Microbiol 2012, 78(14):4949-4958.

17. Stevenson DM, Weimer PJ: Dominance of Prevotella and low abundance of classical ruminal bacterial species in the bovine rumen revealed by relative quantification real-time PCR. Appl Microbiol Biotechnol 2007, 75(1):165-174.

18. Li M, Penner GB, Hernandez-Sanabria E, Oba M, Guan LL: Effects of sampling location and time, and host animal on assessment of bacterial diversity and fermentation parameters in the bovine rumen. J App/ Microbiol 2009, 107(6):1924-1934.

19. Tajima K, Aminov Rl, Nagamine $T$, Matsui $H$, Nakamura M, Benno Y: Diet-dependent shifts in the bacterial population of the rumen revealed with real-time PCR. App/ Environ Microbiol 2001, 67(6):2766-2774.

20. Lettat $A$, Nozière $P$, Silberberg $M$, Morgavi DP, Berger C, Martin C: Rumen microbial and fermentation characteristics are affected differently by bacterial probiotic supplementation during induced lactic and subacute acidosis in sheep. BMC Microbiol 2012, 12:142-154.

21. Hernandez-Sanabria E, Goonewardene LA, Wang Z, Durunna ON, Moore SS, Guan LL: Impact of feed efficiency and diet on adaptive variations in the bacterial community in the rumen fluid of cattle. Appl Environ Microbial 2012, 78(4):1203-1214.

22. Livak KJ, Schmittgen TD: Analysis of relative gene expression data using real-time 401 quantitative PCR and the $2^{-\Delta \Delta C T}$ Method. Methods 2001, 25:402-408.

23. Chaucheyras-Durand F, Fonty G: Influence of a probiotic yeast (Saccharomyces cerevisiae CNCM I-1077) on microbial colonization and fermentation in the rumen of newborn lambs. Microb Ecol Health Dis 2002, 14(1):30-36.

24. Krrížová L, Richter M, Třináctý J, Říha J, Kumprechtová D: The effect of feeding live yeast cultures on ruminal $\mathrm{pH}$ and redox potential in dry cows as continuously measured by a new wireless device. Czech J Anim Sci 2011, 56(1):37-45.

25. Chaucheyras F, Fonty G, Bertin G, Gouet P: Effects of live Saccharomyces cerevisiae cells on zoospore germination, growth, and cellulolytic activity of the rumen anaerobic fungus, Neocallimastix frontalis $\mathrm{MCH} 3$. Curr Microbiol 1995, 31:201-205

26. Bach A, Iglesias C, Devant M: Daily rumen pH pattern of loose-housed dairy cattle as affected by feeding pattern and live yeast supplementation. Anim Feed Sci Tech 2007, 136(1-2):146-153.

27. Newbold CJ, Mclntosh FM, Wallace RJ: Changes in the microbial population of a rumen-simulating fermenter in response to yeast culture. Can J Anim Sci 1998, 78:241-244. 
28. Rossi F, Luccia AD, Vincenti D, Cocconcelli PS: Effects of peptidic fractions from Saccharomyces cerevisiae culture on growth and metabolism of the ruminal bacteria Megasphaera elsdenii. Anim Res 2004, 53:177-186.

29. Monnerat JP, Paulino PV, Detmann E, Valadares Filho SC, Valadares RD, Duarte MS: Effects of Saccharomyces cerevisiae and monensin on digestion, ruminal parameters, and balance of nitrogenous compounds of beef cattle fed diets with different starch concentrations. Trop Anim Health Prod 2013, 45(5):1251-1257.

30. Chaucheyras-Durand F, Fonty G: Establishment of cellulolytic bacteria and development of fermentative activities in the rumen of gnotobiotically-reared lambs receiving the microbial additive Saccharomyces cerevisiae CNCM 1-1077. Reprod Nutr Dev 2001, 41:57-68.

31. Carro MD, Lebzien $P$, Rohr $K$ : Influence of yeast culture on the in vitro fermentation (Rusitec) of diets containing variable portions of concentrates. Anim Feed Sci Tech 1992, 37(3-4):209-220.

doi:10.1186/2049-1891-5-24

Cite this article as: Ding et al:: Effect of Saccharomyces cerevisiae on alfalfa nutrient degradation characteristics and rumen microbial populations of steers fed diets with different concentrate-to-forage ratios. Journal of Animal Science and Biotechnology 2014 5:24.

\section{Submit your next manuscript to BioMed Central and take full advantage of:}

- Convenient online submission

- Thorough peer review

- No space constraints or color figure charges

- Immediate publication on acceptance

- Inclusion in PubMed, CAS, Scopus and Google Scholar

- Research which is freely available for redistribution 